\title{
Traditional Medical Teaching Methods May be a near Future Solution
}

\author{
* Srinath Kamineni \\ Associate Professor in Orthopedics and Sports Medicine, University of Kentucky, USA
}

Submission: October 01, 2017; Published: October 13, 2017

*Corresponding author: Srinath Kamineni, Associate Professor in Orthopedics and Sports Medicine, Director of Elbow Shoulder Research Centre (ESRC), University of Kentucky, Lexington, Kentucky, USA, Email: srinathkamineni@gmail.com

\section{Letter To Editor}

\section{Dear Editor}

I am disheartened by the direction of medical education and its implementation at the grass roots level. Like so many other institutions, my own University teaching Hospital has recently discarded its cadaveric facility in favor of virtual teaching methodologies. This has been a visible trend for several years across universities and hospitals in North America and Europe. Although there is a significant cost saving in education with this departure from traditional methods, a loss of core knowledge from future medically related students is an unspoken price for all future generations to pay.

The detrimental effects that this departure is creating are obvious to see for those of us who teach the current generation of medical students, science students, and surgical residents. Firstly, the lack of practical handling of soft tissues from an early stage of training prevents potential surgeons from developing an innate sense of how soft tissues behave, how inter muscular and inter- neuromuscular planes can be developed, and how different instruments can be used in different ways during surgical approaches. Secondly, when taught by programmed software developed by a human being, the complexity of human normal variation in anatomy is discarded. However, when treating patients, the single most troubling discovery for residents in training, and newly educated independent surgeons, is anatomical variations they have never read about, understood, or have been taught formally or by self-discovery during cadaveric dissection. Thirdly, when anatomy is being taught and understood by a medical student or resident, the time to truly understand the anatomy itself, without the pressure of relating it to pathological changes, is very important and best achieved in isolation, but taught with relevance to the future need for pathological correlation.
My own education was in a traditional two years of preclinical sciences followed by three years of clinical sciences, deliberately chosen above the more modern universities teaching an integrated program from the first year onwards. I have subsequently taught in institutions with a traditional curriculum, and now a much more virtual non contact curriculum. Furthermore, I have seen medical students and surgical residents from both systems, and it is very clear to me that the traditionally taught students have a much greater grasp of how to problem solve patient diagnoses, and have a better tactile ability during surgical procedures, than those from an integrated non contact teaching background.

It is certain that virtual teaching methodologies will improve, more tactile sensation will be built into software programs, anatomical variations will be programmed into the training applications, and remains what is considered to be the future of education. Unfortunately it is currently inadequate and we are crippling our current and future generations with a substandard method of teaching them core knowledge and skills. The current and future generations of medically related students and surgical residents deserve the core knowledge and skills that will make them into safe and productive professionals, with their knowledge preventing a steep increase in litigation, especially for recently independent practitioners.

Those responsible for educating the current and future generations should pay heed to the connection between litigation and the standards of education, and may wish to reconsider the current direction of medical education. A return to more traditional methods, in some circles deemed old-fashioned, may prove to be a valuable investment in our future generations. 
This work is licensed under Creative Commons Attribution 4.0 Licens

DOI: 10.19080/APBIJ.2017.03.555615
Your next submission with Juniper Publishers will reach you the below assets

- Quality Editorial service

- Swift Peer Review

- Reprints availability

- E-prints Service

- Manuscript Podcast for convenient understanding

- Global attainment for your research

- Manuscript accessibility in different formats ( Pdf, E-pub, Full Text, Audio)

- Unceasing customer service

Track the below URL for one-step submission https://juniperpublishers.com/online-submission.php 